\title{
Phacoemulsification and pars plana vitrectomy: no evidence of an increased risk of aerosol transmission
}

\author{
Peter Cackett $\mathbb{D}^{1} \cdot$ Harry Bennett ${ }^{1}$
}

Received: 14 May 2020 / Revised: 26 May 2020 / Accepted: 1 June 2020 / Published online: 15 June 2020

(c) The Royal College of Ophthalmologists 2020

Chandra et al. in their recent paper published in Eye described the current situation regarding the use of personal protective equipment (PPE) for vitreoretinal surgery during COVID-19 [1]. They advised that appropriate PPE including FFP3 masks for surgeons and nurses be used during phacoemulsification and pars plana vitrectomy (PPV). We would like to inform readers that in Scotland, we have received guidance from Health Protection Scotland [2] that in conjunction with World Health Organisation Guidance from 2014 [3], there is no evidence of an increased risk of aerosol transmission in a list of procedures which includes phacoemulsification and PPV. This guidance has been agreed in collaboration with experts from New and Emerging Respiratory Virus Threats Advisory Group and Public Health England.

\section{Compliance with ethical standards}

Conflict of interest The authors declare that they have no conflict of interest.
Publisher's note Springer Nature remains neutral with regard to jurisdictional claims in published maps and institutional affiliations.

\section{References}

1. Chandra A, Haynes R, Burdon M, Laidlaw A, Neffendorf J, Eames I, et al. Personal protective equipment (PPE) for vitreoretinal surgery during COVID-19. Eye (Lond). 2020:1-4. [Epub ahead of print].

2. Health Protection Scotland Document www.hps.scot.nhs.uk Assessing the evidence base for medical procedures which create a higher risk of respiratory infection transmission from patient to healthcare worker. https://www.hps.scot.nhs.uk/web-resources-conta iner/assessing-the-evidence-base-for-medical-procedures-which-crea te-a-higher-risk-of-respiratory-infection-transmission-from-patient-tohealthcare-worker/ (2020).

3. World Health Organization. Infection prevention and control of epidemic-and pandemic prone acute respiratory infections in health care. WHO guidelines. https://www.who.int/csr/bioriskreduction/ infection_control/publication/en/ (2014).
Peter Cackett

pdcackett@hotmail.com

1 Princess Alexandra Eye Pavilion, Chalmers Street, Edinburgh EH3 9HA, UK 